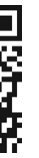

\section{Cumhuriyet Üniversitesi Araștırma ve Uygulama Hastanesi Hemodiyaliz Ünitesi Hastalarının HBsAg ve Anti HCV Seropozitiflikleri}

\author{
The seropositivity of HBsAg and HCV of the Patients from Cumhuriyet University Research and \\ Practice Hospital Hemodialysis Unit
}

\author{
Özlem KAPLAN1, Mustafa Zahir BAKICI2, Cem ÇELIK2, Mansur KAYATAŞ3, Ferhan CANDAN3 \\ ${ }^{1}$ Cumhuriyet Üniversitesi Tıp Fakültesi Hemodiyaliz Ünitesi, Sivas, Türkiye \\ ${ }^{2}$ Cumhuriyet Üniversitesi Tıp Fakültesi, Tıbbi Mikrobiyoloji Anabilim Dalı, Sivas, Türkiye \\ ${ }^{3}$ Cumhuriyet Üniversitesi Tip Fakültesi, Nefroloji Bilim Dalı, Sivas, Türkiye
}

\section{ÖZET}

Amaç: Çalışmamızda, Cumhuriyet Üniversitesi Araşıırma ve Uygulama Hastanesi Hemodiyaliz Ünitesi'ne başvuran hastaların HBsAg ve Anti HCV test sonuçlarının incelenerek pozitiflik dağııımlarının belirlenmesi, sonuçların yaş, cinsiyet, yerleşim yeri, hastalık tablosu gibi faktörler açısından değerlendirilerek bu konudaki literatüre katkı sunulması amaçlanmıştır.

Gereç ve Yöntemler: Hastanemiz hemodiyaliz ünitesine, 01.01.200231.12.2011 tarihleri arasında başvuran 3023 hastanın $\mathrm{HBsAg}$ ve Anti HCV test sonuçları, hemodiyaliz ünitesi ve klinik mikrobiyoloji laboratuvar sonuçları değerlendirilerek geriye dönük olarak incelenmiştir.

Bulgular: Çalışmamı süresi içerisinde başvuran, 1696'sı (\%56) erkek, 1327 'si (\%44) kadın, toplam 3023 hasta HBsAg ve Anti HCV testlerinin sonuçları açısından değerlendirilmiştir. Seropozitiflik HBsAg için \%3,5, AntiHCV seropozitifliği ise \%5,1 olarak tespit edilmiștir. HBsAg ve Anti HCV'nin birlikte görüldüğü olguların oranı ise \% 0,2 olarak bulunmuştur. Kronik böbrek yetersizliği olan hastalarda Anti HCV pozitifliğine, akut böbrek yetersizliği olan hastalarda ise $\mathrm{HBsAg}$ pozitifliğine daha sık rastlanmıştır. Şehir merkezinde yașayanlarda Anti HCV, şehir merkezi dıșında yaşayanlarda HBsAg'ye daha sık rastlanmıştır. Çalışmamızda HBsAg ve Anti HCV pozitifliğinin yaş gruplarına göre dağılımı istatistiksel açıdan anlamlı bulunmamış; ancak 60-69 yaş aralığında sıklığın arttığı görülmüştür.

Sonuç: Çalışmamız süresi içerisinde hastanemiz hemodiyaliz ünitesinde elde edilen HBsAg ve Anti HCV pozitifliklerinin, ülkemiz ortalamasının altında olduğu görülmüștür. Hemodiyaliz merkezlerinin enfeksiyon kontrol önlemlerini etkin bir şekilde uygulaması, sağ|ık çalışanları, personel, hemodiyaliz hastaları ve yakınlarının düzenli eğitimlerle bu konularda bilgilendirilmesi, seropozitif hastalara bakım veren personel ve ekipmanların ayrılması, hastaların serolojik takip ve aşılanmalarının yapılmasında gereken hassasiyetin gösterilmesi gibi önlemlerle daha düşük HBsAg ve Anti HCV sonuçlarına ulaşılabileceğine inanmaktayız. (Viral Hepatit Dergisi 2013; 19(3): 126-30)

Anahtar Kelimeler: Hemodiyaliz, HBsAg, Anti HCV

\section{ABSTRACT}

Objective: The aim of this study is to examine and determine the positive distributions of HBsAg and Anti-HCV test results of the patients who applied to Cumhuriyet University Training and Application Hospital Haemodialysis Unit. We evaluated these results in terms of the factors such as age, gender, settlement and sickness table to make a contribution to the literature.

Materials and Methods: The HBsAg and Anti-HCV test results of 3023 patients applying to haemodialysis unit of our hospital between 01.01.2002 and 31.12.2011 were examined retrospectively by evaluating the test results of haemodialysis unit and clinical microbiology laboratory.

Results: In our study, total 3023 patient applying to our unit, 1696 male (56\%) and 1327 female $(44 \%)$, were evaluated in terms of the HBsAg and Anti-HCV test results. Seropositivity was $3.5 \%$ for HBsAg and $5.1 \%$ for Anti-HCV. The proportion of subjects with both HBsAg and Anti-HCV was $0.2 \%$. Anti-HCV positivity was frequently seen in the patients with chronic renal failure and HBsAg was frequently seen in the patients with acute renal failure. While anti-HCV positivity was seen more in in chronic renal failure patients, $\mathrm{HBs} A g$ positivity was more frequent in acute renal failure patients. Anti-HCV was frequently seen in the patients living in downtown and HBsAg was frequently seen in the patients living in uptown. In our study, no statistically significant difference was found among the distribution of HBsAg and Anti-HCV positivity by age groups; however, the frequency increased in 60-69 age range.

Conclusion: We determined that HBsAg and Anti-HCV positivity obtained from the haemodialysis unit of our hospital were below the country average. We believe that lower HBsAg and Anti-HCV results could be achieved by controls of infection control commitees in haemodialysis centres. Also informing the medical staff, personnel, haemodialysis patients and their relatives about these topics with regular trainings and separating the staff who give care to the seropositive patients and equipment from the others and showing the necessary sensitivity in serologic follow-up and vaccination of the patients can decrease the rate. (Viral Hepatitis Journal 2013; 19(3): 126-30)

Key words: Haemodialysis, HBsAg, Anti-HCV

Yazıșma Adresi/Address for Correspondence: Dr. Cem Çelik, Cumhurivet Üniversitesi Tıp Fakültesi, Tıbbi Mikrobiyoloji Anabilim Dalı, Sivas, Türkiye GSM: +905058834085 E-mail: cemcelik58@gmail.com Geliş tarihi/Received:19.07.2013 Kabul tarihi/Accepted: 08.10.2013 


\section{Giriş}

Günümüzde viral hepatitler halk sağlığı açısından önemini korumaktadır. Hepatit B virüsü (HBV) ve hepatit $C$ virüsü $(H C V)$ prevalansının, hemodiyaliz hastaları gibi özel gruplarda topluma göre daha yüksek bulunduğu bilinen bir gerçektir (1).

Hemodiyaliz hastalarında sık kan transfüzyonu yapılması, hemodiyalizin vasküler girişim gerektirmesi, ileri yaş, çok sayıda hastanın aynı ortamda hemodiyalize girmesi, hastalardaki düşük bağışıklığın duyarlıı̆̆ arttırması, sık hastaneye yatış ve cerrahi girişim uygulanması enfeksiyon riskini artıran etmenlerdir. Hemodiyaliz programındaki hastalar, sürekli ayaktan periton diyalizi ve evde hemodiyaliz uygulanan hastalardan daha yüksek enfeksiyon oranlarına sahiptir (2).

Ülkemizde HBsAg pozitifliği son çalışmalarda, sağlıklı bireylerde \%1-3, Anti-HCV pozitifliği ise \%1 civarlarında bildirilirken, hemodiyaliz hastalarında ise bu oranlar sırası ile $\% 4$ ve $\% 8,5$ olarak bildirilmektedir $(1,3)$.

Çalışmamızda, Cumhuriyet Üniversitesi Araştırma ve Uygulama Hastanesi Hemodiyaliz Ünitesi'ne 01.01.2002-31.12.2011 yılları arasında başvuran hastaların HBsAg ve Anti HCV test sonuçlarının incelenerek pozitiflik dağılımlarının belirlenmesi, sonuçların yaş, cinsiyet, yerleşim yeri, hastalık tablosu gibi faktörler açısından değerlendirilerek bu konudaki literatüre katkı sunulması amaçlanmıştır.

\section{Gereç ve Yöntem}

Çalışmamızda 3023 hastanın HBsAg ve Anti HCV test sonuçları, hemodiyaliz ünitesi ve klinik mikrobiyoloji laboratuvar sonuçları değerlendirilerek geriye dönük olarak araştırımıştır. Tekrarlanan hastalar değerlendirmeye alınmamıştır.

2002-2008 yılları arasında hepatit şüphesi ile gönderilen ve acil olarak çalışılması istenen örnekler Abbott marka (ABD) test kitleri ile diğer örnekler ise Biokit marka (Ispanya) test kitleri ile çalışımıştır. 2009 yılından itibaren ise tüm örnekler Abbott marka test kitleri kullanılarak çalışımıştır. Doğrulama testleri için tüm çalışma süresi boyunca Innolia HCV Score (Belçika), Monolisa HBsAg Ultra Confırmatory (Fransa) test kitleri kullanıımıştır.

Abbott marka test kitleri, Abbott Axsym ve Architect makro ELISA cihazları kullanılarak üretici firma çalışma talimatları çerçevesinde çalışımıştır. Biokit marka test kitleri, Best 2000 ve Triturus mikro ELISA cihazları kullanılarak çalışılmıştır. HCV

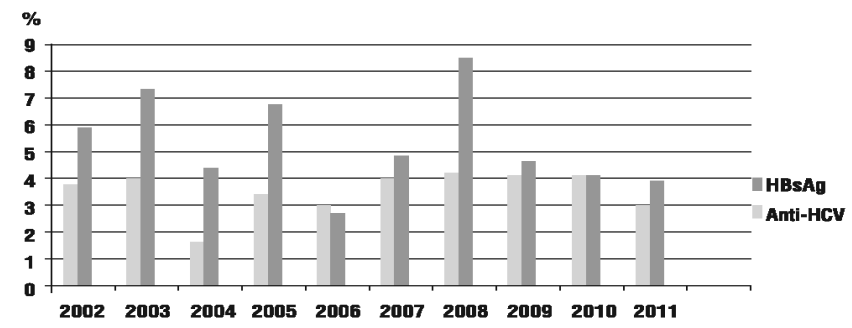

Şekil 1. Hemodiyaliz Ünitesine başvuran hastaların içinde HBs Ag ve anti-HCV pozitif hastaların oranının (\%) yıllara göre dağılımı.
Doğrulama testi, AUTO-LIA II cihazında, Innogenetics marka INNOLIA HCV Score test kitleri kullanılarak, HBs Ag doğrulama testi Monolisa HBsAg Ultra Confırmatory test kitleri kullanılarak Best 2000 ve Triturus sistemlerinde üretici firma çalışma talimatları çerçevesinde çalışılmıştır.

Çalışmamızda tüm pozitif olgular, böbrek yetersizliği tablosunun akut ya da kronik oluşu, yaş aralıkları ve yerleşim yeri kriterlerine göre gruplandırımış, çıkan sonuçlar SPSS 15.0 paket programında ki-kare testi uygulanarak istatistiksel değerlendirmeye alınmıştır.

Çalışmamızda böbrek fonksiyonlarının ani kaybı ile idrar atıımının başarısızlığıyla sonuçlanan ve buna bağlı olarak kan üre azotu ve serum kreatinin miktarı artan hastalar akut, glomerüler filtrasyon değerinde azalmanın sonucu böbreğin sıvı-solüt dengesini ayarlama ve metabolik-endokrin fonksiyonlarında kronik ve ilerleyici bozulma hali olan hastalar ise kronik böbrek yetersizliği olarak tanımlanmıştır $(4,5)$.

\section{Bulgular}

Bu çalışmada 1696'sı erkek, 1327'si kadın, toplam 3023 hasta HBsAg ve Anti HCV testlerinin sonuçları açısından değerlendirilmiş, 33 kadın ve 74 erkek hastada HBsAg; 75 bayan ve 79 erkek hastada ise Anti HCV pozitifliğine rastlanmıştır. HBsAg pozitifliği oranları kadın hastalarda \%1,1, erkek hastalarda \%2,4'tür. Anti HCV pozitifliği ise kadın hastalarda \%2,5, erkek hastalarda \%2,6 oranlarındadır. Seropozitiflik HBsAg için \%3,5 olup vakaların \%30,6'sı kadın, \%69,4'ü erkektir. Anti-HCV seropozitifliği ise $\% 5,1$ olup hastaların \%48,4'ü kadın, \%51,6'sı erkektir. HBsAg ve Anti HCV'nin birlikte görüldüğü olguların oranı ise \%0,2 olarak bulunmuştur (Tablo 1).

Hemodiyaliz hastalarının belirtilen tarihleri arasındaki HBsAg ve Anti HCV pozitifliğinin yıllara göre dağılımı grafikle gösterilmiştir (Şekil 1).

Tablo 1. Hemodiyaliz ünitesine başvuran hastaların son on yıldaki HBsAg ve Anti HCV oranları

\begin{tabular}{|l|c|c|}
\hline Serolojik durum & Toplam sayı & Oran ( \% ) \\
\hline Seronegatiflik & 2762 & 91,2 \\
\hline Anti HCV pozitif & 154 & 5,1 \\
\hline HBsAg pozitif & 107 & 3,5 \\
\hline HBsAg + Anti HCV pozitif & 5 & 0,2 \\
\hline
\end{tabular}

Tablo 2. Hemodiyaliz Ünitesine başvuran hastalardaki HBs Ag ve Anti HCV pozitifliklerinin böbrek yetersizliği tablosuna göre dağııımı

\begin{tabular}{|l|l|l|l|l|}
\hline \multicolumn{2}{|l|}{ Böbrek yetersizliği tablosu } & HBsAg & Anti HCV & Toplam \\
\hline \multirow{3}{*}{ KBY } & Sayı & 69 & 120 & 189 \\
\cline { 2 - 5 } & $\%$ & 36,5 & 63,5 & 100,0 \\
\hline \multirow{3}{*}{ ABY } & Sayı & 38 & 34 & 72 \\
\cline { 2 - 5 } & $\%$ & 52,8 & 47,2 & 100,0 \\
\hline \multirow{2}{*}{ Toplam } & Sayı & 107 & 154 & 261 \\
\cline { 2 - 5 } & $\%$ & 40,2 & 59,8 & 100,0 \\
\hline \multirow{2}{*}{$\chi^{2}=5,14 ; p=0,023 ; p<0,05$} & \multicolumn{5}{|l}{} \\
\hline
\end{tabular}




\begin{tabular}{|l|l|l|l|l|}
\hline $\begin{array}{l}\text { Tablo 3. Hemodiyaliz Ünitesine başvuran hastalardaki HBsAg ve Anti HCV } \\
\text { pozitifliklerinin yerleşim yeri kriterine göre dağllımı }\end{array}$ \\
\hline Yerleşim yeri & & HBsAg & Anti HCV & Toplam \\
\hline \multirow{2}{*}{ Şehir merkezinde } & Sayı & 51 & 99 & 150 \\
\cline { 2 - 5 } & $\%$ & 34,0 & 66,0 & 100,0 \\
\hline \multirow{2}{*}{ Şehir merkezi dışında } & Sayı & 56 & 55 & 111 \\
\cline { 2 - 5 } & $\%$ & 50,5 & 49,5 & 100,0 \\
\hline \multirow{2}{*}{ Toplam } & Sayı & 107 & 154 & 261 \\
\cline { 2 - 5 } & $\%$ & 41,0 & 59,0 & 100,0 \\
\hline$\chi^{2}=7.13 ; p=0,008 ; p<0,05$ & \multicolumn{4}{|l}{} \\
\hline
\end{tabular}

Çalışmamızda, böbrek yetersizliği tablosu ile hepatit belirteçleri arasındaki bağlantı istatistiksel açıdan anlamlı bulunmuştur $(p<0,05)$. Sonuçlara göre KBY olan hastalarda Anti HCV pozitifliğine, ABY olan hastalarda ise HBsAg pozitifliğine daha sık rastlanmıştır (Tablo 2).

Çalışmamızda yerleşim yeri kriterine göre HBsAg ve Anti HCV pozitif olgular karşılaştırılı̆̆ında farklıık önemli bulunmuştur. Şehir merkezinde yaşayanlarda Anti HCV, şehir merkezi dışında yaşayanlarda HBsAg'ye daha sık rastlanmıştır $(p<0,05)$. (Tablo 3).

Çalışmamızda HBsAg ve Anti HCV pozitifliğinin yaş gruplarına göre dağılımı istatistiksel açıdan anlamlı bulunmamış; ( $p>0,05$ ) ancak 60-69 yaş aralığında sıklığın arttığı görülmüştür (Tablo 4).

\section{Tartıșma}

Türkiye'de HBsAg ve Anti HCV seroprevalansları çoğunlukla kan donörlerini kapsayan çalışmalarda araştırılmıştır. Ülkemizde 1989-1999 yılları arasında kan merkezlerinde yapılan çalışmalarda HBsAg pozitifliği \%5,2 olarak bulunurken, 2000-2005 yıllarında bu oran ortalama \%2,97 olarak saptanmıştır. 2005 yılından günümüze kadar yapılan çalışmalarda ise bu oran \%1'ler civarına gerilemiştir. Yine Anti HCV pozitifliği ile ilgili olarak da \%0,5 civarlarında kan donörü pozitiflikleri bildirilmektedir $(1,3,6)$.

Çalışmamızdaki; HBsAg $(\% 3,5)$ ve Anti HCV $(\% 5,2)$ pozitiflikleri kan donörlerine oranla daha fazladır. Kan donörleri çoğunlukla genç ve sağlıklı bireylerden oluşmaktadır. Hemodiyaliz hastaları ise, ileri yaş, sekonder kronik hastalıklar, daha çok invazif girişim, kan ve kan ürünleri nakli, nozokomiyal bulaş ve bağışıklık sistemlerinin zayıf olması gibi nedenlerle hepatit $B$ ve hepatit $C$ gibi bir çok enfeksiyon hastalığına daha yatkındırlar. Bu durumun çalışmamızdaki elde ettiğimiz yüksek pozitiflik oranlarının nedenleri olabileceğini düşünmekteyiz.

Hemodiyaliz hastalarında HBsAg ve Anti HCV görülme sıklıkları için yurt dışında farklı bölgelerden HBsAg için \%2,6 ile \%15, Anti $\mathrm{HCV}$ için ise \%7 ile \%31,1 arasında çalışma sonuçları bildirilmiştir. Yine bu çalışmalarda her iki virüs ile enfekte olan hasta sayısı \%1-2 civarlarında görülmektedir.(7-13) Ülkemizde yapılan çalışmalarda ise hemodiyaliz hastalarında HBsAg için \%5 ile \%9, Anti HCV için \%6-\%21 arasında oranlar bildirilmiştir (14-21).

Ülkemizde hemodiyaliz hastalarında son verilere göre ortalama olarak \%3,9 HBsAg ve \%8,5 Anti HCV pozitiflik oranları bildirilmektedir (3). Çalışmamızda hemodiyaliz hastalarında elde ettiğimiz \%3,5 HBsAg pozitifliği ülkemiz verileri ile uyumlu iken, \%5,2 Anti HCV pozitiflik oranı

\begin{tabular}{|l|l|c|c|c|}
\hline \multicolumn{5}{|l}{ Tablo 4. Hemodiyaliz Ünitesine başvuran hastalardaki HBsAg ve Anti HCV } \\
pozitifliklerinin yaş gruplarına göre dağıııı \\
\hline Yaş grupları & & HBsAg & Anti HCV & Toplam \\
\hline & Sayı & - & 7 & 7 \\
\hline $\mathbf{2 0 - 2 9}$ & $\%$ & - & 4,5 & 2,7 \\
\hline & Sayı & 7 & 12 & 19 \\
\hline $\mathbf{3 0 - 3 9}$ & $\%$ & 6,5 & 7,8 & 7,3 \\
\hline & Sayı & 13 & 22 & 35 \\
\hline $\mathbf{4 0 - 4 9}$ & $\%$ & 12,1 & 14,3 & 13,4 \\
\hline & Sayı & 20 & 27 & 47 \\
\hline $\mathbf{5 0 - 5 9}$ & $\%$ & 18,7 & 17,5 & 18,0 \\
\hline & Sayı & 36 & 56 & 92 \\
\hline $\mathbf{6 0 - 6 9}$ & $\%$ & 33,6 & 36,4 & 35,2 \\
\hline & Sayı & 26 & 28 & 54 \\
\hline $\mathbf{7 0 - 7 9}$ & $\%$ & 24,3 & 18,2 & 20,7 \\
\hline & Sayı & 5 & 2 & 7 \\
\hline $\mathbf{8 0 +}$ & $\%$ & 4,7 & 1,3 & 2,7 \\
\hline & Sayı & 107 & 154 & 261 \\
\hline Toplam & $\%$ & 100,0 & 100,0 & 100,0 \\
\hline$\chi^{2}=9,21 ; \mathrm{p}=0.162 ;$ & $\mathrm{p}>0,05$ & & & \\
\hline & \multicolumn{5}{|l}{} \\
\hline
\end{tabular}

ülkemiz ortalamasının altında görülmektedir. Cumhuriyet Üniversitesi Hastanesi Hemodiyaliz Ünitesi'nde hemodiyaliz sürecinde hepatit enfeksiyonunun gelişmesine rastlanmamış, hastaların ya geldiklerinde hepatit enfeksiyonuna sahip oldukları, ya da diyaliz ünitesine hepatit tanısı almış olarak döndükleri gözlenmiştir. Ünite kurulduğundan bu yana hepatit B ve C'li hasta makinelerinin ayrıması, çalışan sayısının elverdiği ölçülerde, seropozitif hastalara bakım veren sağlık personelinin ayrılması, makine ve çevre dezenfeksiyonunun uygun şekilde ve etkin yapılması, hepatit belirteçlerinin belli aralıklarla takip ediliyor olması, aşılama konusunda hassasiyet gösterilmesi, tüm dünyada ve ülkemizde olduğu gibi eritropoetin ve demir tedavisiyle birlikte hastanede yatma, kan ve kan ürünü naklinin azalması, bilinçlendirme eğitimlerinin etkin yapılmasının bu durumda etken olabileceğini düşünmekteyiz.

Çalışmamızda hepatit belirteçleri ile yaş aralıkları arasında istatistiksel bir anlamlılık bulunmamış, ancak 60-69 yaş aralığında yığılma olduğu saptanmıştır. Barut ve ark. (22) yaptıkları çalışmada anti-HCV pozitif olguların yaklaşık üçte ikisinin 50 yaş üzerinde olduğunu bildirmişlerdir. Yıldırım ve ark. (23) yaşa özgü prevalansın 40'ı yaşlardan sonra artmaya başladığı, 50-59 yaş grubunda $\% 4,2$, 60-69 yaş grubunda \%3,4, 70-79 yaş grubunda ise $\% 7,1$ olarak saptamışlardır. Enginyurt ve ark.(24) çalışmalarında HBsAg pozitifliği olan hasta grubunda 40-49 yaş aralığında yığılma olduğunu bildirmişlerdir.

Çalışmamızda 60-69 yaş aralığında tespit edilen yoğunluk diğer çalışmalarda 50 yaş üstünde seropozitifliğin artması yönündeki sonuçlarla uyumludur. Hemodiyaliz hastalarının çoğunlukla ileri yaşlarda olmalarının, hastanede yatış ve hemodiyaliz süresi uzadıkça da hepatit enfeksiyonu ile daha çok karşılaşma risklerinin çalışmamızdaki 60-69 yaş aralığındaki yığılmayı anlamlı kılacağı düşünülmektedir. 
Hemodiyaliz hastalarında yerleşim alanlarının incelendiği çalışmalarda Asan ve ark. (25) yaptıkları çalışmada HBsAg pozitifliğini kent merkezinde \%4,66, kırsal alanda \%3,52, antiHCV pozitifliğini ise kent merkezinde \%1,07, kırsal alanda \%0,76 olarak bildirmişlerdir. Yerleşim bölgesinin değerlendirildiği bir başka çalışmada ise Kandemir ve ark. (26) HBsAg pozitifliğini kentsel bölgede \%3,6, kırsal bölgede \%6,8 olarak bildirilmişlerdir. Anti-HCV prevalansı genel popülasyonda \%1,1 olarak bulunmuş, kentsel ve kırsal bölgeler için ise oranlar birbirine çok yakın olarak bildirilmiştir.

Çalışmamızda şehir merkezinde yaşayan hastalarda Anti HCV, şehir merkezi dışında yaşayan hastalarda ise HBsAg daha yüksek bulunmuştur. Ulaşım olanakları ve imkânlar neticesinde sağlık kurumlarına daha sık gitme, dolayısıyla da daha çok invazif girişime maruz kalma, damar içi madde kullanımı gibi olası faktörlerin şehir merkezlerinde daha fazla olması, şehir merkezindeki Anti HCV yüksekliğinin; kentte yaşayan popülasyona oranla daha fazla birden fazla eş ile evlilik, aile yapısının geniş olmasına bağı horizontal geçiş, daha fazla sosyal paylaşımlar, şehir merkezi dışındaki HBsAg yüksekliğinin nedeni olabileceği düşünülmüştür.

Çalışmamızda hastalar, böbrek yetersizliği tablosuna göre (ABY, $\mathrm{KBY}$ ) incelenmiş, KBY olan hastalarda anti-HCV pozitifliği, $A B Y$ olan hastalarda ise HBsAg pozitifliği daha yüksek bulunmuştur. Ülkemizdeki çalışmalarda hemodiyaliz hastalarının bu şekilde gruplandırımasına rastlanmamasına rağmen, çeşitli kronik hasta gruplarında yapılan çalışmalarda yüksek pozitiflik oranları elde edildiği görülmüştür (27-29).

Çalışmamız süresi içerisindeki on yıl boyunca Cumhuriyet Üniversitesi Hastanesi Hemodiyaliz Ünitesi'nde rastlanılan HBsAg ve Anti HCV pozitifliklerinin, ülkemiz ortalamasının altında olduğu görülmüştür (7). Hemodiyaliz merkezlerinin enfeksiyon kontrol önlemlerini etkin bir şekilde uygulaması, sağlık çalışanı ve personelin düzenli eğitimlerle bu konularda bilgilendirilmesi, seropozitif hastalara bakım veren personel ve ekipmanların ayrılması, hastaların serolojik takip ve aşılanmalarının yapılmasında gereken hassasiyetin gösterilmesi, hasta takip ve tedavisinin etkin bir şekilde yapılarak hastaneye yatışların azalıılması, bulaş yolları ve hijyene yönelik hemodiyaliz hastaları ve yakınlarının bilgilendirilmesi ve daha geniş çaplı eğitimlerle halkın bilinçlendirilmesi durumunda daha düşük HBsAg ve Anti HCV sonuçlarına ulaşılabileceğine inanmaktayız.

\section{Çıkar Çatıșması: Bildirilmemiștir.}

\section{Kaynaklar}

1. Tosun S. Türkiye'de viral hepatit B epidemiyolojisi yayınlarının meta analizi. Viral Hepatit 2013. Ed: Tabak F, Tosun S. Viral hepatitle savaşım derneği. Istanbul tıp kitapevi 1. baskı. 2013; 25-80.

2. Nicolardi E, Grieco A, Rapaccini GL, Pompili M. Natural history, diagnosis and treatment of chronic hepatitis $B$ and $C$ in hemodialysis patients. G Ital Nefrol.2010; 27(3): 262-73.

3. Mıstık R. Hepatit C virüs enfeksiyonunun epidemiyolojisi. Viral Hepatit 2013. Ed: Tabak F, Tosun S. Viral hepatitle savaşım derneği. Istanbul tıp kitapevi 1. baskı.2013; 81-112.
4. Tanrıverdi MH. Akut böbrek yetersizliği. KonuralpTıp Derg. 2010; 2(1): 46-52.

5. Braunwald E, Faucı AS, Kasper DL, Hauser SL, Longo DL, Jameson JL. Harrison Iç Hastalıkları Prensipleri Çev ed: Sağlıker Y. Nobel Tıp Kitabevleri. 5.baskı. 2004; 1551-66.

6. Mıstık, R. Türkiye'de viral hepatit epidemiyolojisi yayınlarının irdelenmesi. Viral Hepatit 2007. Ed. Tabak F. Balık I. Tekeli E. Viral Hepatitle Savaşım Derneği, Ankara, 2007; 8-53.

7. Su Y, Yan R, Duan Z, Norris JL, Wang L, Jiang $Y$, et al. Prevalence and risk factors of hepatitis $C$ and $B$ virus infections in hemodialysis patients and their spouses: A multicenter study in Beijing, China. J Med Virol. 2013; 85(3): 425-32.

8. Zahedi MJ, Moghaddam SD, Alavian SM, Dalili M. Seroprevalence of hepatitis viruses B, C, D and HIV infection among hemodialysis patients in kerman province, South-East Iran. Hepat Mon. 2012; 12(5): 339-43.

9. Gasim GI, Hamdan HZ, Hamdan SZ, Adam I. Epidemiology of hepatitis $B$ and hepatitis $C$ virus infections among hemodialysis patients in Khartoum, Sudan. J Med Virol. 2012; 84(1): 52-5.

10. Paniagua R, Villasis-Keever A, Prado-Uribe MC, Ventura-Garcia MJ, Alcantara-Ortega G, Ponce de Leon SR, et al. Elevated prevalence of hepatitis $B$ in Mexican hemodialysis patients. A multicentric survey. Arch Med Res. 2010; 41(4): 251-4.

11. Alashek WA, Mclntyre CW, Taal MW. Hepatitis B and C infection in haemodialysis patients in Libya: prevalence, incidence and risk factors. BMC Infect Dis. 2012; 12: 265.

12. Moreira RC, Deguti MM, Lemos MF, Saraceni CP, Oba IT, Spina AMM, et al. HBV markers in haemodialysis Brazilian patients: A prospective 12-month follow-up. Mem Inst Oswaldo Cruz. 2010; 105(1): 107-8.

13. Kalantar-Zadeh K, Kilpatrick RD, McAllister CJ, Miller LG, Daar ES, Gjertson DW, et al. Hepatitis C virus and death risk in hemodialysis patients. J Am Soc Nephrol. 2007; 18(5): 1584-93.

14. Çiçek ÇA, Şahin OZ, Topaloğlu MK, Kazancı TAA, Yenilmez IH, Şahin K, ve ark. Rize ilinde hemodiyaliz hastalarında HBsAg, Anti-HBs ve Anti-HCV seroprevalansı. Viral Hepatit Derg. 2013; 19(1): 15-8.

15. Sırmatel F, Sırmatel Ö, Usalan C, Barlıoğlu C, Göymen A, Kepekçi $\mathrm{E}$, ve ark. Hemodiyaliz hastalarında viral hepatit $\mathrm{B}$ ve $\mathrm{C}$ seroprevalansı. Infeksiyon Derg. 2008; 22(1): 23-8.

16. Kadanalı A, Pirimoğlu S, Özden K. Hemodiyaliz hastalarında HBsAg, Anti-HBs, Anti-HBc Total, Anti-HBc IgM, Anti-HCV ve Anti-HAV IgG Sıklığı. Viral Hepatit Derg. 2004; 9(1): 41-5.

17. Balk M, Saydam G, Cengiz D, Türkmen A, Ayturan I, Himmetoğlu T. Hemodiyaliz hastalarında hepatit $C$ virüs enfeksiyonunun taranması. Türk Biyokimya Derg. 2004; 29(3); 243-6.

18. Bozkurt I, Aygen B, Yıldız O, Gökahmetoğlu S. Bölgemizdeki hemodiyaliz hastalarında hepatit C virusu infeksiyonunun sıklığı ve epidemiyolojik özellikleri. Klimik Derg. 2011; 24(3): 167-72.

19. Arabacı F, Oldaçay M. Çanakkale ilinde farklı diyaliz merkezlerinde tedavi gören hastalarda hepatit B,C seroprevalansı ve hepatit kronikleşme oranları, Türk Hij Den Biyol Derg. 2009; 66(4): 1617.

20. Bahçebaşı ZB, Alçelik A, Korkmaz U, Öztürk E. Hemodiyaliz ünitemizdeki hepatit $C$ virus seroprovelansı ve ünite içi bulaşın önlenmesi. Mikrobiyol Bult. 2004; 38(4): 489-90.

21. Kaygusuz, TÖ. Kronik hemodiyaliz hastalarında HBsAg ve AntiHBs seroprevalansı. F.Ü. Sağ Bil Derg. 2007; 21(2): 55-7. 
22. Barut S, Erkorkmaz U, Yuce S, Uyeturk U. Tokat Gaziosmanpaşa Üniversitesi hastanesinde Anti-HCV pozitif hastalarda risk faktorlerinin analizi, Mikrobiyol Bult. 2008; 42(4): 675-80.

23. Yıldırım B, Barut $S$, Bulut Y, Yenişehirli G, Özdemir M, Çetin I, et al. Seroprevalence of hepatitis $B$ and $C$ viruses in the province of Tokat in the black sea region of Turkey: A population-based study, Turk J Gastroenterol. 2009; 20(1): 27-30.

24. Enginyurt Ö, Aksöz MK. Hepatit B taşıyıcılarının ailelerinde HBsAg taraması, Güncel Gastroenteroloji Derg. 2012; 16(1): 50-2.

25. Asan A, Akbulut A, Saçar S, Turgut, H. Tunceli Devlet Hastanesine başvuran kişilerde HBsAg ve Anti-HCV seroprevalansının değerlendirilmesi. Viral Hepatit Derg. 2011; 17(2): 52-6.
26. Kandemir Ö, Göksu M, Kurt Ö. Mersin ili kentsel bölge ve kent merkezine bağlı belde köy sağlık ocağı bölgesinde hepatit B ve C sıklığı. Viral Hepatit Derg. 2011;17(2): 74-83.

27. Altındiş $M$, Orman A, Ünlü $M$, Kırlangıç Y. Kronik obstrüktif akciğer hastalığı olan bireylerde hepatit C virüs infeksiyonu sıklığı. Viral Hepatit Derg. 2004; 9(2): 76-81.

28. Okan V, Araz M, Demirci F, Karslıgil T, Sezer A, Micozkadıoğlu H, ve ark. Tip 2 Diabetes Mellituslu olgularda hepatit $B$ ve $C$ virüs prevalansı. Viral Hepatit Derg. 2000; 6(3): 179-81.

29. Şencan I, Şahin I, Sertbaş Y, Balbay Ö, Bulut I. Kronik hastalığa sahip olanlarda HBV ve HCV seroprevalansı. Viral Hepatit Derg. 2003; 8(2): 111-5. 